\title{
The Role of Protein Glycosylation in Allergy
}

\section{Friedrich Altmann}

Divison of Biochemistry, Department of Chemistry, University of Natural Resources and Applied Life Sciences, Vienna, Austria

\section{Key Words}

Allergens, clinically irrelevant $\cdot$ Carbohydrate epitopes · Cross-reactive carbohydrate determinant - Glycoprotein • $\mathrm{N}$-glycosylation $\cdot \mathrm{O}-/ \mathrm{N}$-linked glycans

\begin{abstract}
The asparagine-linked carbohydrate moieties of plant and insect glycoproteins are the most abundant environmental immune determinants. They are the structural basis of what is known as cross-reactive carbohydrate determinants (CCDs). Despite some structural variation, the two main motifs are the xylose and the core-3-linked fucose, which form the essential part of two independent epitopes. Plants contain both epitopes, insect glycoproteins only fucose. These epitopes and other fucosylated determinants are also found in helminth parasites where they exert remarkable immunomodulatory effects. About $20 \%$ or more of allergic patients generate specific anti-glycan IgE, which is often accompanied by lgG. Even though antibody-binding glycoproteins are widespread in pollens, foods and insect venoms, CCDs do not appear to cause clinical symptoms in most, if not all patients. When lgE binding is solely due to CCDs, a glycoprotein allergen thus can be rated as clinical irrelevant allergen. Low binding affinity between IgE and plant $\mathrm{N}$-glycans now drops out as a plausible explanation for the benign nature of CCDs. This rather may result from blocking antibodies induced by an incidental 'immune therapy' ('glyco-specific immune therapy') exerted by everyday contact with plant ma-
\end{abstract}

terials, e.g. fruits or vegetables. The need to detect and suppress anti-CCD IgE without interference from peptide epitopes can be best met by artificial glycoprotein allergens. Hydroxyproline-linked arabinose (single $\beta$-arabinofuranosyl residues) has been identified as a new IgE-binding carbohydrate epitope in the major mugwort allergen. However, currently the occurrence of this O-glycan determinant appears to be rather restricted. Copyright $\odot 2007 \mathrm{~S}$. Karger AG, Basel

\section{Introduction}

The word carbohydrate is a potent stop signal for the 'readosome' of a typical allergist. This is unfortunate because carbohydrate determinants are almost certainly the most frequently encountered individual epitope structures for IgE. They have therefore been baptized cross-reactive carbohydrate determinants (CCDs) [1]. Fortunately for patients who have developed IgE against CCDs, the clinical effect of these antibodies appears to be negligible in most cases [2-5]. At first instance, the carbohydrate nature of CCDs appears to hold a simple explanation for this phenomenon, but for the impartial biological chemist, carbohydrates are not by nature molecules of minor significance. This review deals with (i) the history and current status of the knowledge on the structure(s) of CCDs in plants, insects and also parasites; (ii) the specificity of animal and human anti-CCD anti-

\section{KARGER \\ Fax +41613061234 \\ E-Mail karger@karger.ch}

www.karger.com
() 2007 S. Karger AG, Basel

$1018-2438 / 07 / 1422-0099 \$ 23.50 / 0$

Accessible online at:

www.karger.com/iaa
Correspondence to: Dr. Friedrich Altmann

Department für Chemie, Universität für Bodenkultur, Wien

Muthgasse 18

AT-1190 Wien (Austria)

Tel. +43136006 6062, Fax +43136006 6059, E-Mail friedrich.altmann@boku.ac.at 
bodies; (iii) the current view of the clinical significance of CCDs and anti-CCD IgE and possible reasons for the innocuous nature of carbohydrate epitopes; (iv) strategies for the improvement of in vitro measurement of $\operatorname{IgE}$ by recognition and inhibition of anti-CCD IgE, and (v) the new but small area of O-glycan epitopes on plant allergens.

The review is confined to protein-linked glycans of known structure. The possibly large and interesting, but to date rudimentary, area of fungal glyco-allergens has been touched elsewhere [6] and will not be presented here.

\section{The Malaise of Allergy Diagnosis by in vitro Measurement of $\operatorname{lgE}$}

It is common ground that type I hypersensitivities (in simple terms: most phenomena usually understood as allergy) are caused by immunoglobulins of class E [7]. Depending on the eliciting agent, $\operatorname{IgE}$ from different patients binds to very different antigens, then called allergens. Remarkably, and not untypical for the current status of this science, the term allergen equally means a single type of molecule containing the IgE-binding determinants as well as the natural package of various molecules and structures, e.g. venoms, pollens or hair, which may then contain several allergens in the molecular sense. On scientific grounds, to support a patient's anamnesis, type I allergies are diagnosed by skin prick testing (SPT) or by in vitro determination of allergen-specific IgE, as far as methods are concerned. The in vitro method has the advantages of being less time consuming (at least for the patient), less painful and of allowing a larger number of allergens to be screened. In theory, reaction of a patient's IgE with a certain allergen extract points to sensitization towards this allergen. The concentration of IgE indicates the severity of allergic symptoms to be expected on contact with the allergen. This prognostic value is of importance especially for allergies having life-threatening potential, e.g. insect venom or peanut allergy. Patients with a high radioallergosorbent test (RAST) class towards bee or wasp venom are advised to always carry with them an emergency set to rescue them in the event of an insect sting.

Unfortunately, the correlation between specific IgE (sIgE) levels and the severity of real clinical symptoms is remarkably loose. On the one side, in vitro tests may fail to detect sIgE and thereby overlook sensitization towards the allergen. This has been observed in the diagnosis of food allergies, e.g. against apple and carrot $[8,9]$, and the reasons may be quite trivial ones such as low stability of the allergen or varying concentrations in the raw material used for extraction. Standardization of allergen extracts for prick testing and serum IgE determination is therefore a challenging and serious task [10]. On the other side, the observation has been made that the mere binding of IgE to components of an allergen extract does not always correlate with the clinical diagnosis obtained by SPT or even by more physiological tests such as a double-blind placebo-controlled food challenge $[2,3,11,12]$. In this review, we will show that $>20 \%$ of allergic patients have IgE that binds to carbohydrate compounds, which are essentially unable to elicit clinical symptoms. These supposedly clinically irrelevant carbohydrate determinants compromise the significance of serum IgE determinations. In vitro reactivity with protein panallergens such as profilin likewise cannot always be taken as an unambiguous indication of the clinical role of carbohydrate determinants [4, 13-15].

\section{A Short History of CCDs}

It all began in the 1970s when a Japanese group elucidated the strange structure of a protease from pineapple [16]. Later, it was confirmed that this bromelain (Brl) contained an oligosaccharide with two structural features, which had not been found in mammalian glycoproteins, i.e. core $\alpha 1,3$-fucose and xylose (fig. 1) [17]. Of note, bromelain is a special case as glycans with three mannose residues are more usually found in plant glycoproteins, e.g. on horseradish peroxidase (HRP; fig. 1) [18-21].

The link between plant glycobiology and allergy was made in 1981 by some short but pioneering work from Aalberse et al. [1]. They showed that IgE from patients' sera cross-reacted with extracts from various allergenic foods as well as with insect venoms, but treating the extracts with periodate abolished the reaction. Conclusions from periodate oxidation experiments must be drawn with caution as this harsh treatment can also destroy peptide epitopes [22]. However, their finding was corroborated by later reports. The first one showed N-glycans were involved in the IgE binding to honeybee venom phospholipase $\mathrm{A}_{2}\left(\mathrm{PLA}_{2}\right.$; Api m 1) [23]. Aalberse et al. [1] had already perceived a connection between reactivity to plant CCDs and a history of insect stings. The structural basis for the cross-reaction of IgE with insect and plant glycoproteins only became evident once the structural particularities of insect $\mathrm{N}$-glycans, i.e. the presence of a 


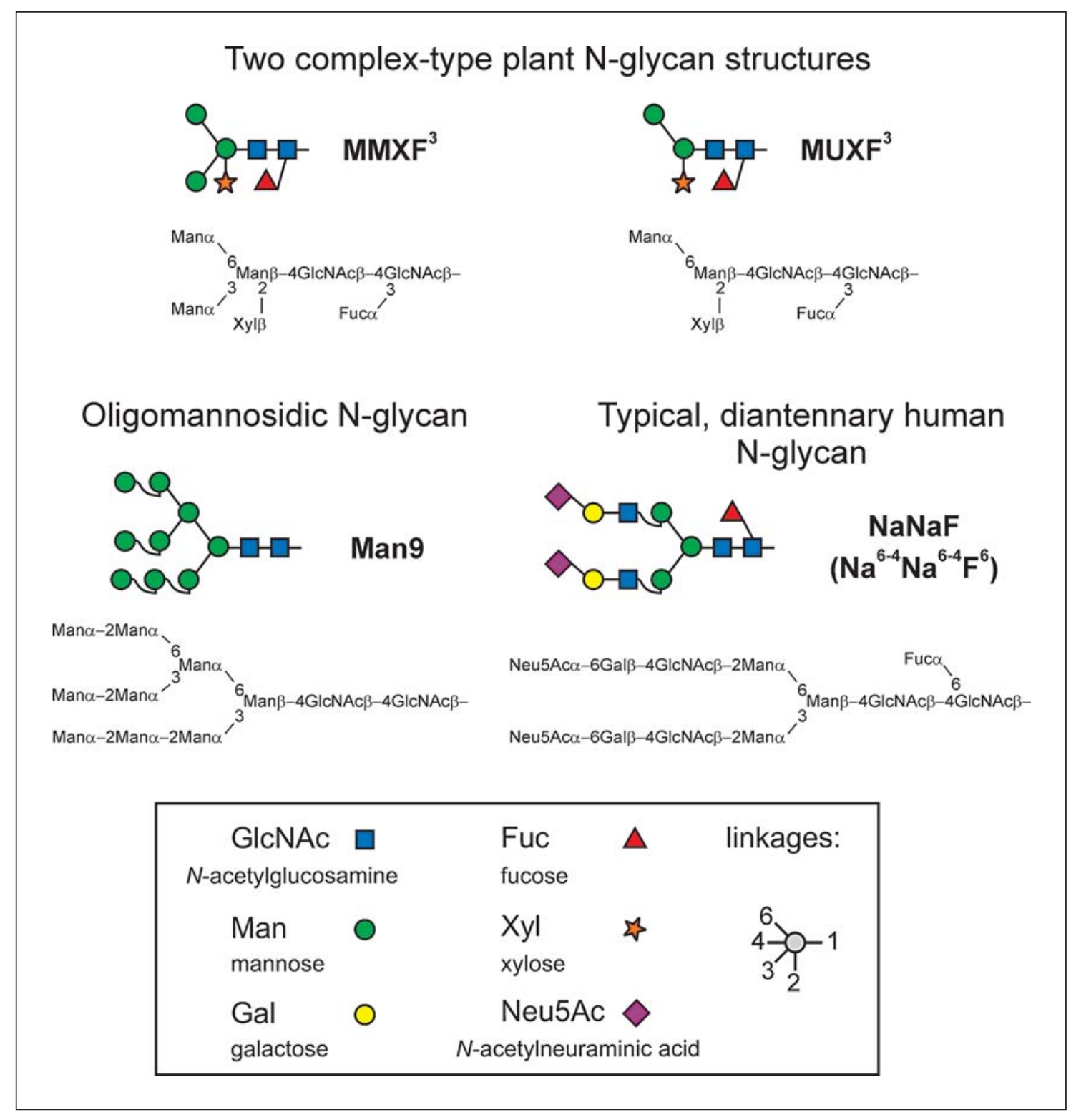

Fig. 1. Comparison of plant and mammalian N-glycans. The oligosaccharide structures are shown in the symbolic depiction suggested by the Consortium of Functional Glycomics (www.functionalglycomics.org) with the additional information about linkage positions. The structure codes comply with the proglycan system (www. proglycan.com). The upper two structures $\mathrm{MMXF}^{3}$ and $\mathrm{MUXF}^{3}$ represent typical complex-type plant N-glycans, e.g. HRP or bromelain, respectively. The Man9 structure is one example of the series of oligomannosetype glycans Man5 to Man9 $\left(\mathrm{Man}_{5} \mathrm{GlcNAc}_{2}\right.$ to $\left.\mathrm{Man}_{9} \mathrm{GlcNAc}_{2}\right)$, which occur in all eukaryotic organisms. The glycan $\mathrm{NaNaF}$ constitutes a typical mammalian complex-type N-glycan with sialic acids. Note the different position of the fucose residues.

core $\alpha 1,3$-fucose just like in plants [24], had been revealed. In sera from patients allergic to bee venom, glycopeptides (GPs) made from pineapple stem Brl were shown to inhibit IgE from binding to Api $m 1$ [24]. As the peptide moieties of such GPs comprise only two to four amino acids at maximum, they hardly constitute epitopes on their own. The conclusiveness of this approach appears much stronger than that of destructive methods such as periodate oxidation or chemical deglycosylation. In the succeeding years, an ever growing number of pa- 
pers reported that anti-CCD IgE was involved in in vitro reactivity of patients' sera to a wide variety of allergens.

\section{Asn-Linked Oligosaccharides in Plants}

Different taxonomic groups are distinguished by different structural features of their Asn-linked glycans (Nglycans) as well as their ability to generate certain types of O-glycans, which will be dealt with in a separate chapter. The biosynthesis of $\mathrm{N}$-glycans is textbook knowledge allowing us to start with the assertion that the first steps of protein $\mathrm{N}$-glycosylation are essentially conserved in all eukaryotic organisms $[25,26]$. The first large phylogenetic group to leave the common trail are fungi, which lack the enzymes that lead to complex-type glycans, e.g. GlcNAc transferase I - at least, this holds true for yeasts [27]. In plants and animals, the Man5 structure is processed by GlcNAc transferase I and subsequently Golgi $\alpha$-mannosidase (often referred to as $\alpha$-mannosidase II) and GlcNAc transferase II. But already at this stage the 'higher animals', i.e. the deuterostomia, begin to deviate from the taxonomic protostomia (e.g. insects), acoelomata (e.g. Caenorhabditis elegans and many parasitic worms) and noteworthily plants [28].

The term plant must be restricted again, as except from the moss Physcomitrella patens [29], all other plants whose $\mathrm{N}$-glycan structures have been investigated belong to the Tracheophyta (vascular plant). However, within these taxonomic limitations, we can claim that all plant species have the same spectrum of N-glycan structures, certainly the angio- and gymnosperms [20], but also ferns and horsetails [Altmann, unpubl. results]. The most important differences from human N-glycans are: (1) the core $\alpha 1,3$-fucose, i.e. the fucosylation of the innermost GlcNAc at position 3; (2) the xylosylation of the $\beta$-mannosyl residue, and (3) the 'premature' termination of the antennae with mannose, GlcNAc or galactose residues instead of sialic acids (fig. 2). A further feature of certain plant glycoproteins is the occurrence of Lewis a determinants, which are branched, terminal trisaccharides made of galactose, fucose and $\mathrm{N}$-acetylglucosamine (fig. 2). Lewis structures are also found in mammals, albeit usually together with sialic acid.

Plants have not been very inventive with their glycan structures. Essentially every plant and plant material contains the entire spectrum of $\mathrm{N}$-glycans but with large quantitative differences $[20,30]$. The very large Lewis a type structures are rarely found on soluble allergens and are currently thought to play only a minor, if any, role in
IgE binding even though many plant foods (apple, banana, celery, onion, orange, pear, and strawberry) contain large amounts of these near-mammalian $\mathrm{N}$-glycans [20]. The cedar pollen allergens Cry $\mathrm{j} 1$ and Jun a 1 are the only allergens known to contain Lewis a antennae [31, 32]. Complex-type glycans without terminal galactose/ fucose comprise the most abundant species in most (food) plants. For isolated allergen proteins, the prototypical Nglycan structure is the so-called $\mathrm{MMXF}^{3}$ (fig. 1). This structure occurs so frequently on plant proteins that trying to list all known carriers would be futile. Examples among non-allergens are HRP [18] and many lectins [33, 34], and among allergens, $\mathrm{Phl} p 1, \mathrm{Phl} p 13$ [35], Lyc e 2 [36] Hev b 4 [37], Lol p 11 [38], and Api g 5 [39]. Tree pollens [30] and tree pollen allergens [39] tend to bear terminal non-reducing GlcNAc residues, a feature which may reduce IgE binding (see paragraph on specificity of IgG). Olive pollen Ole e 1, hazelnut Cor a 11 and peanut Ara $\mathrm{h} 1$ differ by essentially lacking the core fucosyl residue $[38,40,41]$. In contrast, Cyn d 24 and other glycoproteins from Bermuda grass pollen carry non-xylosylated glycans, mainly $\mathrm{MMF}^{3}$ (fig. 2) $[42,43]$.

Important to understand is that the nature of the protein to which such sugar chains are attached is irrelevant, comparable to a traffic light for which it hardly matters where and how exactly it is mounted. Having said this, cases where the protein moiety may affect presentation of carbohydrate determinants can admittedly be found. An example is phospholipase, the major protein of honeybee venom (see also next paragraph). In immunoblots with anti-CCD sera, the much less abundant hyaluronidase stains stronger [44]. The glycan profiles of these allergens hardly pose an explanation for this difference [45]. To stay with the above picture, the traffic light could be shielded by the branch of a tree.

\section{Asn-Linked Oligosaccharides (N-Glycans) of Insects}

Core $\alpha 1,3$-fucose is regularly found in insect glycoproteins, e.g. in honeybee venom PLA $_{2}[46,47]$ and hyaluronidase $[40,45]$, and in yellow jacket venom hyaluronidases [48]. Most often it is accompanied by a second, $\alpha 1,6$-linked fucose (fig. 2). Apart from insect venoms, this cross-reactive structure is found in neuronal cells of insects $[18,28]$. Xylosylation has never been found in insect glycoproteins. Proteins from house dust mites, despite their phylogenetic relationship, are probably not core 3-fucosylated as they fail to bind rabbit anti-CCD antibodies [19]. 


\section{Asn-Linked Oligosaccharides of Snails and Parasitic Worms}

Immunogenic glycans with both xylose and core $\alpha 1,3$ fucose have been found in parasitic worms (helminths) such as Schistosoma mansoni and S. japonica or Haemonchus contortus (fig. 2) [49-53]. Given the considerable problems associated with the analysis of glycoproteins from such sources, a large number of unknown cases can be expected. Core $\alpha 1,3$-fucosylated glycans have not been found in cercaria of $S$. mansoni [49], which may point to a stage- and/or tissue-specific expression of this determinant. Snail glycoproteins have been shown to contain xylose residue [54-56]. Although the relevant fucosyltransferase could be detected in the snail Lymnea stagnalis [57], only traces of core $\alpha 1,3$-fucosylated glycans could hitherto be found in snails [55].

It is crucial to appreciate that parasitic helminths, e.g. schistosomes, express additional glyco-antigens on the non-reducing side of $\mathrm{N}$-glycans as well as O-glycans [50, 58-63]. Apart from the well-known Lewis x structure, several determinants have been found with GalNAc-containing LacdiNAc antennae instead of the usual Gal-containing LacNAc antennae [reviewed in ref. 58, 59]. LacdiNAc structures may be fucosylated or difucosylated and they may form repeats. Even substitution of fucosyl residue by fucose has been found [63, 64]. Remarkably, some of these glyco-determinants also appear in mollusks, which are phylogenetically quite distant to helminths $[60,65]$. These - for mammals - highly unusual structures elicit generation of antibodies of all kinds of classes $[58,66]$ and they induce granuloma formation [60]. Most importantly, they skew the host immune system towards a Th2 response [66-70]. At the same time, the course of the Th2 response is attenuated by downregulatory cytokines (e.g. IL-10) [58, 59, 66, 71].

Sheep infected with parasites generate mainly IgE against glyco-determinants, some of which are also found in plant and insect glycoproteins [52]. Nevertheless, the immune response to such parasites does not resemble allergic hypersensitivity. On the contrary, there is evidence that a history of infection by parasitic worms strongly reduces the allergy risk by restraining the Th2 responses against allergens [59, 72]. Parasite glycoconjugates have not yet been directly associated with allergy. However, one could meditate if the immunomodulatory nature of parasite glycans on the one hand and the apparently benign conduct of glyco-allergens on the other are purely coincidental phenomena.

\section{Specificity and Affinity of IgG Raised against Plant Glycoproteins}

Despite the long history of carbohydrates as immunogens - just think of blood group antigens or bacterial polysaccharides (used for example in the Haemophilus influenzae type b vaccine) - allergologists originally met the idea of anti-glycan antibodies of the IgE class with considerable skepticism if not sheer rejection. Differences in serum reactivity between glycosylated and non-glycosylated allergens were discounted as changes in protein structure induced by the glycans or just as another kind of non-specific binding. Therefore, the thorough characterization of the epitope structure recognized by rabbit, goat or rat antibodies was an important prerequisite for the appreciation of plant $\mathrm{N}$-glycans as specific antibody determinants on their own, both for IgG and IgE.

Concomitant with the first observations on the immunogenicity of plant $\mathrm{N}$-glycans, conclusions about the chemical nature of the carbohydrate epitope were drawn based on the structural difference between plant and human glycans. At first, the xylose residues were implicated as the essential element $[73,74]$. Detailed work on the HRP epitope corroborated this finding and added the core $\alpha 1,3$-linked fucose as a second antibody-binding element [18]. With the discovery of core $\alpha 1,3$ fucose in insect glycoproteins $[45,46]$, it became apparent that this widely distributed residue is involved in cross-reactions between plant and insect glycoproteins. Using different forms of Brl-GPs and oligosaccharides, it could be shown that only reducing glycans or GPs - but not reductively aminated or reduced oligosaccharides - inhibit rabbit anti-HRP from binding to various glycoproteins including honeybee venom PLA (Api m 1) [24]. Besides, $0.3 \mu \mathrm{M}$ GP was required to achieve $50 \%$ inhibition of antibody binding [24]. At about that time, rabbit serum raised against carrot $\beta$-fructosidase or HRP was successfully fractionated into a 'fucose-specific' and a 'xylose-specific' fraction by affinity chromatography on immobilized PLA [75]. This work re-introduced xylose as a CCD. Interestingly, later work on the cross-reaction of anti-HRP and of a rat monoclonal antibody did not indicate any substantial contribution of xylose [19, 76]. The conclusions on the structure of the CCD were drawn from inhibition experiments with Brl-GP or defucosylated Brl-GP. A reason for the inconsistent findings about the role of xylose may be that Brl contains $\mathrm{MUXF}^{3}$ (or simpler: MUXF), a truncated version lacking one mannose residue, instead of the more common $\mathrm{MMXF}^{3}$ (or MMXF) structure (fig. 1). In fact, MUXF was recently found to be

Int Arch Allergy Immunol 2007;142:99-115 
Fig. 2. Glycans of plants, insects and parasites. a Some complex-type N-glycans as found in plants. The lack of terminal GlcNAc or Lewis a determinants of either of the two antennae generates additional combinations. The non-xylosylated $\mathrm{MMF}^{3}$ glycan found in Bermuda grass [42] is shown in c. b Examples of $\mathrm{N}$-glycans found in snails and parasitic helminths. c Typical core 3-fucosylated $\mathrm{N}$-glycans from insect venoms.

Fig. 3. Model of a CCD. The cartoon depicting the $3 \mathrm{D}$ structure of the most abundant CCD N-glycan $\mathrm{MMXF}^{3}$ was emulated from Bouwstra et al. [79]. It shows that the core $\alpha 1,3$-fucose (shown in red) and the 6-linked mannose lie on the same side of the glycan whereas the xylose (in blue) is located at the opposite side. Thus xylose and fucose form independent epitopes. The cartoon shall, however, not be understood the way that the two types of antibody can bind simultaneously to the same molecule.

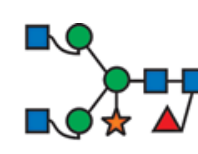

GnGnXF ${ }^{3}$

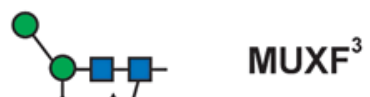

Shat maxse

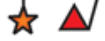

qua

MUX

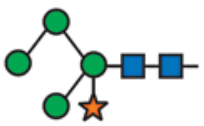

Man4X
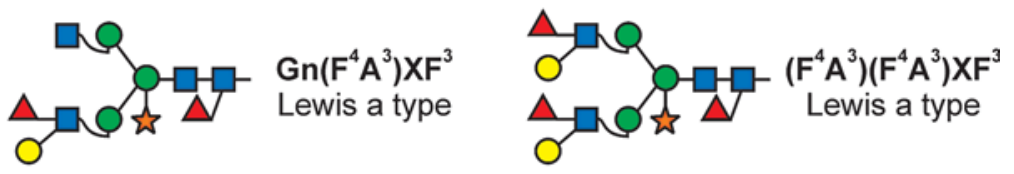

MMX

Man4X
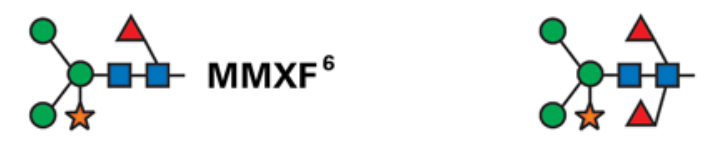

$\mathrm{MMXF}^{3} \mathrm{~F}^{6}$

\section{b}
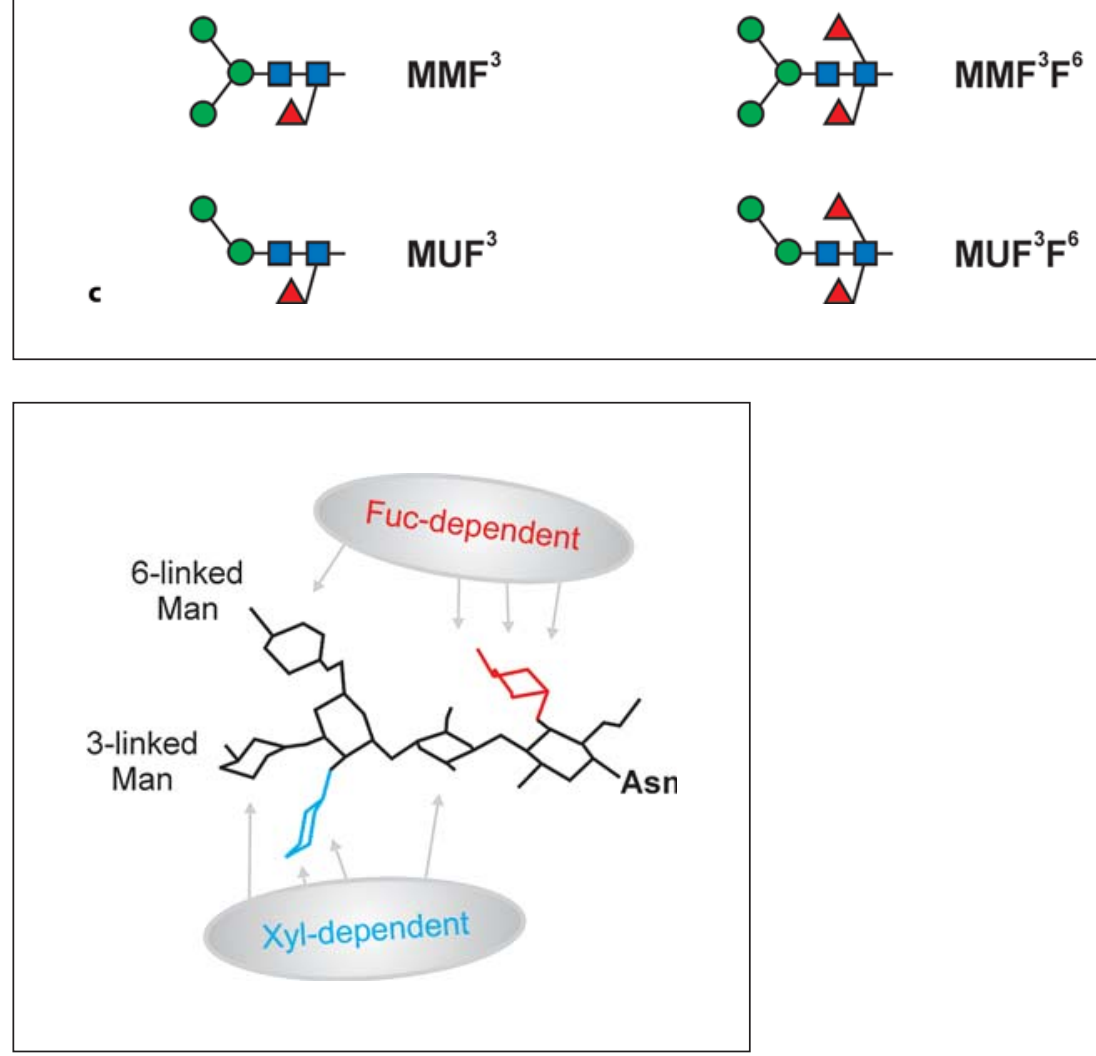
a poorer ligand for Xyl-dependent antibodies than MMXF [77]. In this work, recombinant xylosyl-transferase and core $\alpha 3$-fucosyl-transferase were used to 'plantify' human apotransferrin that had been treated with glycosidases to carry GnGn oligosaccharides, which serve as substrate for the glycosyltransferases [77]. No hint of a comparable influence of the presence or absence of the $\alpha 3$-linked mannose on the binding of fucose-dependent antibodies has been found. The different dependence of the xylose and the fucose epitopes on $\alpha 3$-mannose may be explicable by the different orientation of xylose and $\alpha 3$-fucose as found in NMR-based modeling studies of the $\mathrm{N}$-glycan of $\mathrm{Brl}[78,79]$.

Another important finding was that efficient binding of anti-HRP, for example, to re-modelled transferrin was only obtained after removal of the GlcNAc-residues at the non-reducing termini, i.e. after the conversion of $\mathrm{GnGnF}$ and GnGnX to MMF and MMX, respectively [77]. This means, that terminal substituents shield the Fuc epitopes and therefore larger plant $\mathrm{N}$-glycans may not function as $\mathrm{CCD}$ despite their content of Xyl and Fuc. Exceptions to this rule may however be found as immunization with MMX glycoprotein, which also contained some GnGnX, elicited antibodies able to bind to GnGnX [80].

Taken together, recent work produced conclusive evidence that plant N-glycans harbor two essentially independent epitopes, one containing core $\alpha 1,3$-fucose and the other one the $\beta 1,2$-linked xylose (fig. 3) $[75,77,80]$. Since in both cases other parts of the oligosaccharide confer individually weak, but in concert important, contributions to the binding of antibodies $[18,77]$, such antiCCD immunoglobulins should not be termed Fuc or Xyl specific but rather Fuc or Xyl dependant. Also, there may be differences in binding strength of similar $\mathrm{N}$-glycans to the same serum as well as small differences in the substrate specificity of antibody populations. However, apart from the above example with MMX, MUX and GnGnX (with or without Fuc), no such differences have been demonstrated.

\section{Species-Related Aspects of the Immune Response}

Some of the above-mentioned studies were probably done on the implicit understanding that what is found for rabbit antibodies would also hold true for human IgG and, hopefully, even IgE. There is, however, no guarantee of such a similarity. For example the murine immune system behaves very different from that of rabbits [77, 81]. Although a monoclonal antibody against Cupressus arizonica glycoproteins could be generated from $\mathrm{Balb} / \mathrm{c}$ mice [82], this strain is usually found not to react measurably against the glycans when immunized with plant glycoproteins [81]. Raising anti-CCD antibodies and generating hybridoma cell lines that produce monoclonal antibodies is apparently easier in C57BL/ 6 mice and rats than elsewhere [19, 81-85]. However, as far as analyzed in detail, these murine antibodies cannot discriminate different truncated complex-type ('paucimannosidic') N-glycans such as MM, $\mathrm{MMF}^{3}$ or MMX [77, 80, 85]. Human IgE, however, has proved able to discriminate $\mathrm{MMF}^{3}$ from MM or MMX [77]. A similar picture can be seen in a study with non-allergic people, where $25 \%$ exhibited IgG binding to honeybee PLA (core $\alpha 3$-fucosylated) whereas 50\% reacted with Helix pomatia hemocyanin, which is known to contain xylose but also a panel of other immunogenic carbohydrate determinants $[65,81$, 86].

\section{Anti-CCD IgE in Allergic Patients}

With growing awareness among allergologists of the existence of IgE-binding carbohydrates, the number of papers implicating glycans as part of an allergen is steadily increasing. Such IgE binding has been observed with insect venoms, grass and tree pollens and foods $[2,11,35$, $36,38,39,44,76,87-104]$. Possibly the first work measuring anti-CCD IgE in individual sera was on a panel of patients allergic to bee venom [24]. From 122 sera, 28\% bound to GPs from bee venom PLA and from Brl, which were coupled to bovine serum albumin (BSA; fig. 4). Only two sera also reacted with a pentasaccharide core devoid of xylose and fucose [24]. The anti-CCD IgE from many of the bee-venom-allergic patients could be inhibited by GPs prepared from pineapple Brl, but not if the GPs had been defucosylated [24]. A similar percentage of CCD reactivity was found in a large study on patients allergic to insect venom [5]. Here, CCD-positive patients were detected on the basis of a positive CAP test with Brl and negative SPT with different pollens. Thus, as admitted by the authors, the $16 \%$ of CCD-positive patients did not include all those who had anti-glycan IgE and at the same time a SPT reaction with pollens - regardless of which allergen molecule had caused the reaction [5]. In studies of carrot and celery allergens, $45-55 \%$ of the sera were CCD positive when tested with Brl-GPs $[11,105]$. Using proteinase-K-digested grass pollen extract as the CCD source, van der Veen et al. [2] showed that one third of 32 patients allergic to grass pollen exhibited anti-CCD $\operatorname{IgE}$, which was responsible for reactivity with peanut in vitro. 
The major work on CCD reactivity is that of Mari [12], where a large cohort of allergic patients who showed reactivity to Brl in vitro was challenged with Brl by SPT. In a CAP assay, 23\% of the sera from 1,831 patients showed IgE to Brl. The prevalence of CCD reactivity somehow correlated with the number of pollens with which the patients gave a positive SPT. However, almost none of the patients had a positive SPT against $\mathrm{Brl}$ (see also next paragraph).

The specificity of human IgE may at first be considered similar to that of rabbit IgG. This can be deduced from studies where Brl-GPs and their defucosylated form were used to inhibit IgE binding to plant glycoproteins $[24,77]$ and from a recent study with biosynthetic glycoallergens [77]. Interestingly, only Fuc-dependant IgE could be detected [77], which may just reflect a coincidental bias in serum selection or the postulated role of insect stings as elicitors of anti-CCD IgE $[2,5]$.

In conclusion, many allergic patients develop specific IgE directed against plant/insect protein-linked glycans. This anti-CCD IgE will lead to 'false-positive' results in in vitro testing whenever natural allergen extracts are used $[3,5,6,72,77]$.

\section{On the Clinical (In)Significance of anti-CCD IgE}

Any patient with anti-CCD IgE would be a very poor creature if glycan epitopes were to trigger severe clinical symptoms like notoriously strong allergens, e.g. Ara h 1 and 2, Bet v 1 or Api m 1, do. Obviously, and fortunately, this is not the case. Several recent studies make a clear point about the clinical insignificance of carbohydrate determinants $[2,4,5,12,38,106,107]$. In these studies, the discrepancies between RAST/CAP and SPT results or other in vivo tests formed the basis of the conclusion. Using proteinase-K-digested grass pollen as the CCD source, van der Veen et al. [2] observed that about one third of patients allergic to grass pollen had a positive RAST with peanut extract but a negative SPT with the same extract or with isolated Ara h 1 or 'Ara h 2'. [From the sequence given, it is rather Ara h 6 (Q9SQG5) than what is now termed Ara h 2 (Q8GV20). For both allergens, the glycoprotein nature is not evident.] The in vitro reactivity was shown to be due to CCD epitopes. As Ara $\mathrm{h} 1$ is monovalent, the soundness of this rationale is arguable. However, a later study by Mari [12] who selected over 1,000 sera with positive CAP against Brl corroborated the observation. The patients from whom the sera had been taken were challenged with three monovalent allergens, i.e. Brl, ascorbate oxidase (P37064) and honeybee phospholipase and the multivalent glycoprotein HRP. In accordance with the theory that cross-linking of IgE receptors on mast cells triggers an allergic response, only HRP elicited a positive SPT in at least $21 \%$ of the patients. The response, which may or may not have actually been caused by the glycans, hardly ever exceeded SPT class II, which is below the threshold above which people visit their doctor [12]. Not to be overlooked, almost $80 \%$ of the patients did not even react with the polyvalent HRP. As a side note, a few patients did react with phospholipase but probably because of a protein-directed sensitization. Thus, as long as HRP is not convicted of being a particularly poor elicitor for whichever reasons, these results score a clear point against a clinical significance of $\mathrm{N}$-glycans.

Kochuyt et al. [5], who concentrated on insect-stingallergic patients, found that allergic patients who were CCD positive to insect stings did not react towards grass pollens in a nasal provocation test. Similar results were found for the glycoproteins orange germin-like protein (Cit s 1) and latex Hev b $2[95,96]$. Also, the carbohydrate of vicilin (mainly MMX) was found not to contribute to eliciting symptoms [41]. Because of this clinical insignificance, CCD epitopes and in many cases also profilin can be seen as 'mimickers of allergy' [4].

\section{Degranulation by Glyco-Allergens}

These observations contrast with several reports on histamine release by glycoproteins and anti-CCD IgE. One of the first of these papers compared the histamine release capabilities of Brl-GPs coupled to BSA (Brl-BSA; fig. 4), defucosylated Brl-BSA, rBet v 1, and celery extract were compared [101]. The concentration of Brl-BSA required to release histamine was about 10 times higher than that of Bet $\mathrm{v} 1$, whereas the celery extract concentration required was up to 1,000 times higher. In other words, natural extracts may be a rather poor source of polyvalent CCD allergens and their comparison with pure protein allergens may be misleading. In a study on natural and recombinant Cup a 1 in several patients, the concentration dependence curves were very similar [92]. Studies with tomato allergens, HRP and Brl-BSA conjugate also favor the idea of a similar potency of CCD [36, 108]. Other studies have not emphasized the quantitative aspect so much $[35,39,89]$. In the case of the olive allergen work, it should be added that deglycosylation by PNGase F cannot be expected to be successful because of the enzyme's restricted substrated specificity and hence the interpretation of the results is difficult $[89,109]$. For patients allergic to peanut, rather high threshold concen- 
Fig. 4. Preparation of CCD reagents. Starting point are glycoproteins containing different N-glycans. a The work flow for bovine fibrin, which contains diantennary $\mathrm{N}$-glycans as shown in figure 1 from which GPs with GnGn and MM structures can be obtained. b Brl with its MUXF N-glycan. c A glycoprotein with a MMXF structure. Digestion with an unspecific protease (usually from Streptomyces griseus) yields GPs with just a few amino acids as depicted in the middle line. These can be chemically coupled to a carrier protein or a solid support, which is symbolized by an oval area. The dotted line from the fibrin GnGn-GP to the MMXF-GP indicates an alternative route, where recombinant glycosyltransferases are used to 'plantify' the mammalian substrate by the addition of xylose and fucose residues to yield GnGnXF GPs in the first place. Removal of GlcNAc residues by $N$-acetylglucosaminidase finally leads to MMXF structures.

Fig. 5. Effective valency of glyco-allergens. Mediator release from mast cells or basophils requires IgE molecules to be crosslinked. Therefore, allergens have to be at least divalent. The left cartoons show models of glycoproteins, which can be considered ineffective because they carry only one glycan (a), or even two glycans but one of them cannot bind IgE because the CCD epitopes are masked by terminal GlcNAcs (blue squares; b) or it is of the oligomannose type (c). The cartoons on the right side depict cases where cross-linking could happen (provided spatial requirements are fulfilled) because of two peptide epitopes (d), a peptide and a CCD epitope (e) or two glycans with CCDs (f). This latter case represents a glycoprotein, which is unrelated to the sensitizing agent and where IgE binding occurs solely on the basis of CCDs.
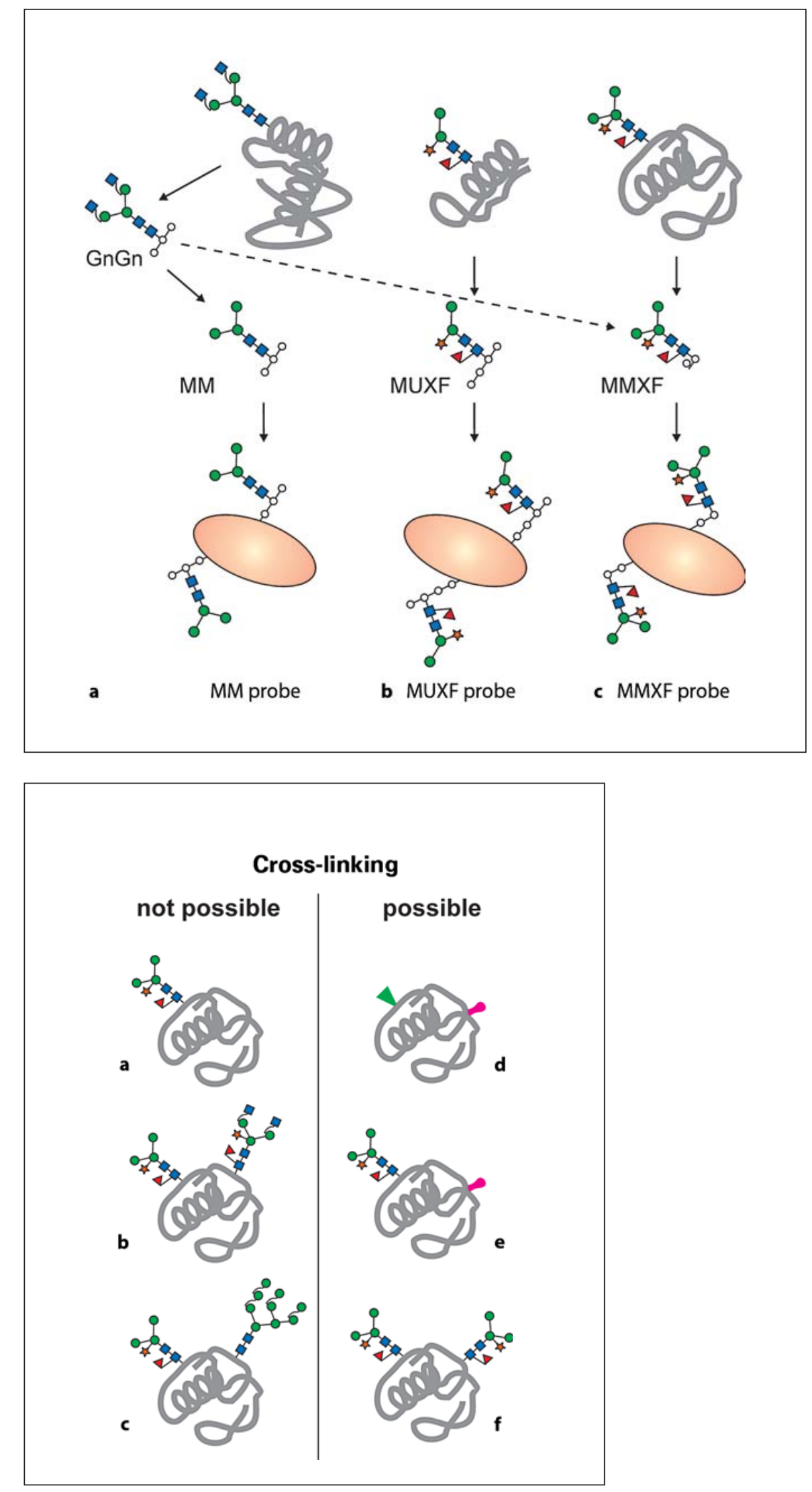
trations were found for peanut extract, Ara $\mathrm{h} 1$ (monovalent) and 'Ara h 2' (or rather Ara h 6) [2]. On the basis of these high threshold concentrations, van Ree [110] proposed low binding affinity of anti-CCD IgEs as an explanation for their weak clinical relevance. Similarily, riceproduced human lactoferrin was able to effect basophil histamine release only at very high concentrations, but it was anyway ineffective in SPT up to $0.5 \mathrm{mg} / \mathrm{ml}$ [presentation by Mari et al. at the XXVth Annual Congress of the European Academy of Allergology and Clinical Immunology (held on June 10-14, 2006, in Vienna)]. Lactoferrin can carry two $\mathrm{N}$-glycans. The major structure in the rice-produced protein was MMXF, however, in mixture with other glycans devoid of fucose. Therefore, the question remains whether a large fraction actually had been at least divalent in terms of core fucose.

In summary, despite conflicting observations about the required dosage for histamine release or disputes about proper test systems, there are strong in vitro indications that glycoproteins can trigger IgE-mediated degranulation of granulocytes and/or mast cells. At the same time, it appears that the in vitro effects are mild. Although the carbohydrate nature of CCDs may have sometimes been taken as an answer to this discrepancy, it does not hold an explanation. Besides, such an attitude affronts the enthusiastic glycobiologist. Carbohydrates stood at the cradle of immunology and they continue to be useful as bacterial antigens, e.g. for Haemophilus influenzae vaccination. How then can the benign nature of plant/insect $\mathrm{N}$-glycans as allergenic determinants be explained?

\section{Reasons for the Clinical Insignificance of CCDs}

A first explanation comes from the requirement of cross-linking of IgE receptors (FceR) on effector cells, which is only met by allergens that are at least divalent. For glycoproteins, this can mean that the allergen harbors peptide epitopes in addition to a CCD (fig. 5). This could be the case if the glycoprotein actually were the sensitizing agent. The sugars are just one additional epitope and their efficacy does not need separate consideration. The other possibility is that the patient's serum solely recognizes glycan determinants on the allergen. Then it would not be sufficient that the glycoprotein carries two, three or more glycan chains, which also must exhibit structures that facilitate antibody binding. Given the structural variety on plant glycoproteins, this may not be so easily fulfilled, and therefore many plant glycoproteins may have little potential to trigger degranulation even though they bind IgE in in vitro tests for which monovalent binding is sufficient. Besides, many of the well- known glyco-allergens are monovalent, e.g. Api $\mathrm{m} 1$ (PLA), Ara h 1, or Phl p 1.

A second, more general hypothesis is based on the relatively high (glyco)protein concentrations required for histamine release, which van Ree [110] suggested was due to an assumed low binding affinity of IgE to glycan epitopes. This hypothesis may have been fuelled by earlier findings on the affinity of animal lectins and their carbohydrate ligands [111]. It does, however, not apply to antibody glycan interactions. In particular, the affinity of rabbit anti-CCD antibodies has recently been determined to be around $10^{-9} \mathrm{M}[80]$. Human anti-CCD IgE likewise appears to have a rather high binding affinity [Jin et al., unpubl. results]. Thus, low binding affinity drops out as an explanation.

A third hypothesis could be formulated if patients' sera were found to contain considerable amounts of blocking antibodies (presumably $\operatorname{IgG}_{4}$ ) of sufficient affinity. Preliminary results from our laboratory favor this idea. Interception of IgE binding by blocking antibodies is one important mechanism contributing to the efficacy of allergy vaccination (specific immunotherapy $=$ SIT) [112-114]. CCD-specific $\operatorname{IgG}_{4}$ antibodies have indeed been found in patients who have received grass pollen immunotherapy [115]. However, the more than 1,000 people examined by Mari [12] and patients in similar studies mentioned above did not receive such treatment. However, these people just like everybody else will have had contact with plant material probably every day of their life. So, many people may undergo an incidental or natural 'immune therapy' ('glyco-SIT') with CCDs before, while or after they are sensitized to glyco-allergens. The situation might resemble that recently described for occupational exposure to animal plasma proteins where some sensitized patients had developed $\mathrm{IgG}_{4}$ levels to apparently protect them from adverse effects [116] and it reminds of the old observation that beekeepers develop high levels of IgG, which protect them from allergic reactions against bee venom. A recent work estimated $25 \%$ of normal healthy people have Fuc-dependent IgG (IgG and $\operatorname{IgM}$ ) [81]. Phospholipase (Api $\mathrm{m} 1$ ) was used as a Fuccontaining test antigen which, however, led to false-positive results due to peptide determinants as well as underestimation because Api $\mathrm{m} 1$ is a relatively poor ligand of anti-CCD IgE [44]. Even more sera reacted with $H$. pomatia hemocyanin, which carries Xyl-containing glycans [56], but binding to other epitopes of a peptide or carbohydrate nature cannot be strictly excluded.

The blocking antibody concept does not contravene positive histamine release as in this semi-physiological 
test, IgG would largely be removed from the assay system.

Regrettably, little is known about the patients' usual age at IgG induction, about the subclass distribution (although a bias towards IgG4 may be assumed), about the relation between IgE and IgG levels and about the relative binding affinities of these antibodies in humans. Can we safely assume that a sufficient level of blocking antibodies is generated in each patient to prevent relevant allergic reactions? Put another way, can we find patients who do respond to CCDs and can conditions be defined where CCDs play a clinical role? Some CCD-reactive, celery-allergic patients were found to develop true allergic symptoms on contact with carrot despite the absence of measurable anti-protein IgE [105]. In some patients, moderate SPT reactions with rape pollen extract likewise could not be explained by epitopes other than CCDs [117]. However, the overwhelming majority of patients with anti-CCD IgE appear to be protected against severe symptoms. It is highly unlikely that physicians would fail to notice if up to $20 \%$ of their patients had allergic episodes after they had ingested virtually every kind of vegetable food. A glycoprotein which binds IgE by CCDs only must therefore be rated as just a clinically irrelevant allergen.

A fascinating side aspect of the glyco-SIT hypothesis is the speculation that the innocuous nature of highly conserved protein panallergens such as profilin could derive from an analogous mechanism. Remember that panallergens from different sources exhibit increasingly different structures with growing phylogenetic distance whereas CCD structures do not vary in this way.

A fourth line of reasoning could be developed from the observation that fucosylated glycoconjugates of parasites interact with components of the innate immune system to facilitate the induction of a Th2 response, which, however, is quantitatively restricted (see paragraph on parasite $\mathrm{N}$-glycans). Although a connection of parasite immune response and allergic response to CCDs is entirely speculative, it might pay to keep an eye on the adjacent borders of these subjects.

\section{Discrimination between Anti-Peptide and Anti-CCD IgE}

Specificity is a core quality of any diagnostic test. Regrettably, because of interference from cross-reactive carbohydrate determinants, serum IgE diagnosis is afflicted by an awkwardly high degree of unspecificity $[5,12,38$, $88,91]$. This has to taken into account whenever extracts of natural allergens from plants and insects are used as antigens as in current in vitro allergy diagnosis. While this may pose a case for recombinant allergens $[118,119]$, more instantaneous solutions are required to improve diagnoses. A good start might be to detect false-positive serum diagnosis of insect venom allergies in patients who react with insect venoms solely because of anti-CCD IgE.

To our mind, a proper strategy would detect whether a particular serum contains anti-CCD IgE and, if so, specifically prevent this IgE fraction from binding to the allergen. These two steps can either be performed consecutively or simultaneously, which means that all sera would be treated in the same way at the outset. For detection, a plant glycoprotein or a 'plantified' mammalian protein (to be explained later) could be used and introduced as an additional 'allergen' in a serum diagnosis work flow. We believe it is high time to solve the CCD problem in serum $\operatorname{IgE}$ diagnosis. Considering the high cost of specific $\operatorname{IgE}$ determinations, a tiny extra expenditure must not be allowed to hinder securing more specific and reliable results. Moreover, current developments towards miniaturization of serum diagnosis by microarray methodology should meet any objections based on cost $[120,121]$. Recognizing a serum as containing anti-CCD IgE is only the first step. The compulsive consequence is to perform sIgE determination in a way that eliminates the reactivity of anti-CCD IgE. This is probably best achieved by adding an inhibitor (other options are discussed below). It must be emphasized that while the presence of antiCCD IgE will lead to many positives only because of sugar-IgE interaction, it does not at all exclude the presence of anti-peptide antibodies capable of triggering adverse reactions against a few allergens. CCD inhibition will allow this anti-protein IgE to be detected in spite of the presence of cross-reactive anti-CCD IgE. The suppression of signal from clinically irrelevant IgE should increase the reliability of serum IgE diagnosis by eliminating most if not all false-positive results.

The CCD inhibitor as well as the CCD pseudo-allergen should have no protein-based IgE reactivity, it should contain the relevant glycan structures, and, to provide high inhibitory potency, it should be a large and polyvalent molecule. Free GPs for example have a poorer inhibitory potency than the same GP coupled to BSA with moderate density has $(<2 \mathrm{~mol} / \mathrm{mol})$ [Dalik and Altmann, unpubl. results]. The first demand is fulfilled by protease digestion of the CCD source, which could be any relatively pure and well-characterized plant glycoprotein, e.g. HRP or pineapple stem Brl [19]. Important results have 
recently been obtained with proteinase-K-digested grass pollen extract $[77,110]$. However, this extract is a rather expensive and heterogeneous source where the absence of residual peptide-based IgE binding has to be ensured. Brl is an inexpensive source but lacks the 3 -arm mannose [16, $19,24]$. As this residue may both have beneficial $[77,110]$ and inhibitory effects [77, 110], especially for Xyl-dependant antibodies, a mixture of MUXF-GP from Brl and MMXF-GPs from another plant glycoprotein might best fulfill the requirements. Digestion with protease (e.g. from Streptomyces griseus) followed by purification of the resulting GPs ensures absence of peptide determinants (fig. 5) $[19,24,39,44,76]$. Coupling of such GPs to an inert carrier increases the inhibitory potency per mole of glycan chain about 100-fold [Dalik and Altmann, unpubl. results]. In addition, these conjugates can be used for ELISA and, due to their polyvalency, for histamine release assays [35]. Preparing control conjugates from mammalian glycoprotein (bovine fibrin) that lack the plant-specific sugars is also possible [24,77]. Alternatives could be plant glycoproteins, e.g. Brl or HRP (multivalent with mainly MMXF glycans), but negative controls, i.e. the protein without plant-specific sugar residues, are not available for them. Therefore, protein-based reactivity cannot be recognized. Besides, Brl may be an odd choice because firstly it is a protease, secondly it just has one glycan, which thirdly has the rare MUXF structure.

Instead of making use of ready-made CCDs of plant glycoproteins, a mammalian glycoprotein can be modified with glycosidases and recombinant glycosyltransferases $[77,80]$. This approach avoids artificial linkers and allows reliable controls to be prepared and, for scientific purposes, distinction between Fuc-dependant and Xyldependant antibodies.

In the following, alternative strategies for interfering with IgE binding to CCDs and their inherent drawbacks are presented.

\section{Other Approaches for Anti-CCD IgE Detection}

Carbohydrate determinants can be destroyed by either periodate or glycosidase treatment [6]. Periodate is a powerful reagent, which abolishes glycan-based IgE reactivity. However, its specificity is occasionally questioned. Indeed, we have recently observed that Art $\mathrm{v} 1$ looses its protein-based, IgE-binding capacity upon mild periodate treatment [22]. Periodate treatment strongly reduced IgE binding by Mal d 1 even though Mal d 2 is not glycosylated [129]. The use of glycosidases is less hampered by unspecificity - although proteases can be an issue - than by the sad fact that peptide $\mathrm{N}$-glycosidases (PNGases) A or F are inefficient, but for different reasons [109]. Treatment with exo-glycosidases, especially $\alpha$-mannosidase, might attenuate the glycan epitopes $[18,19]$. However, both terminal $\alpha$-mannosidases must be removed quantitatively, which can only be achieved by rather high enzyme doses [45]. An only temporary solution could be the use of proteinase $\mathrm{K}$ for example to destroy any proteinbound reactivity. Persisting IgE binding indicates carbohydrate epitopes [6]. However, converting a large and polyvalent allergen into small monovalent fragments may in itself interfere with the test system in various ways leading to lower IgE binding.

\section{Discrimination of Glycan and Peptide Epitopes of Allergens}

One important route to understanding allergy is the molecular characterization of individual allergens, which in its ultimate format includes the definition of all relevant epitopes. Although this an ambitious and laborious task, it is pretty simple to assess the relative importance of IgE binding to peptide versus carbohydrate epitopes using the above-described CCD allergens as inhibitor. It is suspected that many high-molecular-weight proteins currently listed as minor allergens merely fell victim to cross-reactive antibodies.

\section{O-Glycans in Plants}

Much has now been said about N-glycans but these are not the only carbohydrates on allergens with the ability to bind IgE even though in our view they will remain the most prominent class of carbohydrate determinants in allergy. Recently, Art v 1, the major allergen of mugwort (Artemisia vulgaris), has been shown to be O-glycosylated in two ways [22]. The prominent glycan, a hydroxyproline-linked arabinogalactan, did not bind serum IgE from allergic patients but the single $\beta$-arabinosyl residues linked to the many, often adjacent, hydroxyproline residues of the non-globular domain of Art $v 1$ did. This new type of carbohydrate determinant explained the different performance of recombinant and natural Art $v 1$ in RASTs [122]. The somewhat lower in vivo reactivity of recombinant as compared to purified Art v 1 may indicate a contribution of the $\beta$-arabinoses to the development of clinical symptoms [123]. The O-glycans of potato lectin have been implicated in IgE binding some time ago $[1,2]$. A cross-reaction of sera binding to Art $\mathrm{v} 1$ with potato lectin was, however, not observed [22]. 
O-glyco-allergens from other weeds are currently unknown. Related plant species might be assumed to equip their proteins with similar determinants. However, what can be guessed from recent work with rabbit anti-Art v 1 serum and various allergen extracts is that the volume of arabinose-based cross-reactivity is not at all comparable with that caused by $\mathrm{N}$-glycans [Léonard, pers. commun.].

\section{Glycans and T Cells/Jokes Played by Lectins/Mammalian CCD}

The immune response to polysaccharides is T-cell independent and therefore rather weak. In contrast, Asnlinked oligosaccharides of honeybee PLA have been found to contribute to the proliferation of some human T-cell clones, which did not respond to unglycosylated PLA [124]. The involvement of the glycan moiety in T-cell responses is well established in cancer immune therapy [125]. Here it should be mentioned that oligosaccharides of Cry j 1 were found to have an inhibitory potential for Cry-j-1-specific T cells [103].

A totally different effect of protein glycosylation was found when calf intestine alkaline phosphatase conjugates were used to identify cat allergens. A strong staining of cat IgA and IgM was revealed to be caused by IgE-independent cross-linking with the phosphatase via patients' anti-glycan IgM [126]. A similar case of reverse glycan binding occurred in immunoblots of banana and pea extracts, where lectins led to direct binding of $\operatorname{IgG}_{4}$ or IgE antibodies, respectively [2, 127].
Finally, a hint at the existence at a yet undiscovered third CCD in mammalian tissues was presented by Wong et al. [128].

\section{Concluding Remarks}

Our knowledge of CCDs in the form of Asn-linked glycans from plants and insects precludes us from ignoring this large group of IgE determinants for any longer. It is high time to implement anti-CCD IgE detection in allergy diagnosis to prevent misdiagnosis. Patients allergic to grass pollen may all too often have been scared by being erroneously categorized as insect venom allergic. To avoid the however apparently small risk of errors in the other direction, the possibility of clinically relevant reactions based on CCDs alone must be investigated by careful evaluation of the IgE specificity data from large numbers of patients. The glyco-SIT hypothesis does not exclude the possibility of severe symptoms due to CCDs. It would, however, suggest that the allergic status of a patient persists only for a short period and that the severity of symptoms decreases over time. Then glycoproteins are clinically irrevelant allergens for this patient.

\section{Acknowledgments}

This work was in part supported by the Austrian Science Foundation (grant S8803). My gratitude goes to Wolfgang Hemmer and Chunsheng Jin for their invaluable recent contributions for the understanding of the role of CCDs in allergy and to Elise Langdon-Neuner for language editing.

\section{References}

1 Aalberse RC, Koshte V, Clemens JG: Immunoglobulin $\mathrm{E}$ antibodies that crossreact with vegetable foods, pollen, and Hymenoptera venom. J Allergy Clin Immunol 1981;68: 356-364.

2 van der Veen MJ, van Ree R, Aalberse RC, Akkerdaas J, Koppelman SJ, Jansen HM, van der Zee JS: Poor biologic activity of cross-reactive IgE directed to carbohydrate determinants of glycoproteins. J Allergy Clin Immunol 1997;100:327-334.

-3 van Ree R: Clinical importance of cross-reactivity in food allergy. Curr Opin Allergy Clin Immunol 2004;4:235-240.
-4 Ebo DG, Hagendorens MM, Bridts CH, De Clerck LS, Stevens WJ: Sensitization to crossreactive carbohydrate determinants and the ubiquitous protein profilin: mimickers of allergy. Clin Exp Allergy 2004;34:137-144.

$\checkmark 5$ Kochuyt AM, Van Hoeyveld EM, Stevens EA: Prevalence and clinical relevance of specific immunoglobulin $\mathrm{E}$ to pollen caused by sting-induced specific immunoglobulin E to cross-reacting carbohydrate determinants in Hymenoptera venoms. Clin Exp Allergy 2005;35:441-447.

6 Malandain H: IgE-reactive carbohydrate epitopes - classification, cross-reactivity, and clinical impact. Allerg Immunol (Paris) 2005;37:122-128.
Bennich HH, Ishizaka K, Johansson SG, Rowe DS, Stanworth DR, Terry WD: Immunoglobulin E: a new class of human immunoglobulin. Immunology 1968;15:323-324.

-8 Rudeschko O, Fahlbusch B, Henzgen M, Schlenvoigt G, Herrmann D, Vieths S, Jager L: Investigation of the stability of apple allergen extracts. Allergy 1995;50:575-580.

-9 Ballmer-Weber BK, Wangorsch A, Bohle B, Kaul S, Kundig T, Fotisch K, van Ree R, Vieths S: Component-resolved in vitro diagnosis in carrot allergy: does the use of recombinant carrot allergens improve the reliability of the diagnostic procedure? Clin Exp Allergy 2005;35:970-978. 
10 van Ree R, Dorpema JW, Vieths S: Allergy vaccines: a need for standardisation in mass units of major allergen. Pharmeuropa Bio 2005;2005:27-30.

-11 Ballmer-Weber BK, Wuthrich B, Wangorsch A, Fotisch K, Altmann F, Vieths S: Carrot allergy: double-blinded, placebo-controlled food challenge and identification of allergens. J Allergy Clin Immunol 2001;108:301307.

-12 Mari A: IgE to cross-reactive carbohydrate determinants: analysis of the distribution and appraisal of the in vivo and in vitro reactivity. Int Arch Allergy Immunol 2002; 129:286-295.

$\checkmark 13$ Weber RW: Patterns of pollen cross-allergenicity. J Allergy Clin Immunol 2003;112: 229-239; quiz 240.

-14 Ferreira F, Hawranek T, Gruber P, Wopfner N, Mari A: Allergic cross-reactivity: from gene to the clinic. Allergy 2004;59:243-267.

15 Wensing M, Akkerdaas JH, van Leeuwen WA, Stapel SO, Bruijnzeel-Koomen CA, Aalberse RC, Bast BJ, Knulst AC, van Ree R: IgE to Bet $\mathrm{v} 1$ and profilin: cross-reactivity patterns and clinical relevance. J Allergy Clin Immunol 2002;110:435-442.

-16 Ishihara H, Takahashi N, Oguri S, Tejima S: Complete structure of the carbohydrate moiety of stem bromelain. An application of the almond glycopeptidase for structural studies of glycopeptides. J Biol Chem 1979; 254:10715-10719.

17 van Kuik JA, Hoffmann RA, Mutsaers JHG, van Halbeek $H$, Kamerling JP, Vliegenthart JF: A $500-\mathrm{MHz}{ }^{1} \mathrm{H}-\mathrm{NMR}$ study on the Nlinked carbohydrate of bromelain. Glycoconj J 1986;3:27-34.

-18 Kurosaka A, Yano A, Itoh N, Kuroda Y, Nakagawa T, Kawasaki T: The structure of a neural specific carbohydrate epitope of horseradish peroxidase recognized by antihorseradish peroxidase antiserum. J Biol Chem 1991;266:4168-4172.

$\checkmark 19$ Wilson IB, Harthill JE, Mullin NP, Ashford DA, Altmann F: Core $\alpha 1,3$-fucose is a key part of the epitope recognized by antibodies reacting against plant $\mathrm{N}$-linked oligosaccharides and is present in a wide variety of plant extracts. Glycobiology 1998;8:651-661.

20 Wilson IB, Zeleny R, Kolarich D, Staudacher E, Stroop CJ, Kamerling JP, Altmann F: Analysis of Asn-linked glycans from vegetable foodstuffs: widespread occurrence of Lewis a, core $\alpha 1,3$-linked fucose and xylose substitutions. Glycobiology 2001;11:261-274.

-21 Lerouge P, Cabanes-Macheteau M, Rayon C, Fischette-Laine AC, Gomord V, Faye L: Nglycoprotein biosynthesis in plants: recent developments and future trends. Plant Mol Biol 1998;38:31-48.

-22 Leonard R, Petersen BO, Himly M, Kaar W, Wopfner N, Kolarich D, van Ree R, Ebner C, Duus JO, Ferreira F, Altmann F: Two novel types of O-glycans on the mugwort pollen allergen Art v 1 and their role in antibody binding. J Biol Chem 2005;280:7932-7940.
23 Weber A, Schroder H, Thalberg K, Marz L: Specific interaction of $\operatorname{IgE}$ antibodies with a carbohydrate epitope of honey bee venom phospholipase $A_{2}$. Allergy 1987;42:464470.

24 Tretter V, Altmann F, Kubelka V, Marz L, Becker WM: Fucose alpha 1,3-linked to the core region of glycoprotein $\mathrm{N}$-glycans creates an important epitope for IgE from honeybee venom allergic individuals. Int Arch Allergy Immunol 1993;102:259-266.

25 Lerouge P, Bardor M, Pagny S, Gomord V, Faye L: N-glycosylation of recombinant pharmaceutical glycoproteins produced in transgenic plants: towards an humanisation of plant N-glycans. Curr Pharm Biotechnol 2000;1:347-354

26 Wilson IB: Glycosylation of proteins in plants and invertebrates. Curr Opin Struct Biol 2002;12:569-577.

27 Bretthauer RK, Castellino FJ: Glycosylation of Pichia pastoris-derived proteins. Biotechnol Appl Biochem 1999;30(Pt 3):193-200.

28 Altmann F, Fabini G, Ahorn H, Wilson IB: Genetic model organisms in the study of Nglycans. Biochimie 2001;83:703-712.

29 Koprivova A, Altmann F, Gorr G, Kopriva S, Reski R, Decker E: N-glycosylation in the moss Physcomitrella patens is organized similarly to that in higher plants. Plant Biol 2003;5:582-591.

30 Wilson IB, Altmann F: Structural analysis of $\mathrm{N}$-glycans from allergenic grass, ragweed and tree pollens: core $\alpha 1,3$-linked fucose and xylose present in all pollens examined. Glycoconj J 1998;15:1055-1070.

31 Kimura Y, Kamamoto M, Maeda M, Okano M, Yokoyama M, Kino K: Occurrence of Lewis a epitope in N-glycans of a glycoallergen, Jun a 1, from mountain cedar (Juniperus ashei) pollen. Biosci Biotechnol Biochem 2005;69:137-144.

32 Maeda M, Kamamoto M, Hino K, Yamamoto S, Kimura M, Okano M, Kimura Y: Glycoform analysis of Japanese cedar pollen allergen, Cry j 1. Biosci Biotechnol Biochem 2005; 69:1700-1705

-33 Ashford DA, Dwek RA, Rademacher TW, Lis $\mathrm{H}$, Sharon N: The glycosylation of glycoprotein lectins. Intra- and inter-genus variation in N-linked oligosaccharide expression. Carbohydr Res 1991;213:215-227.

34 Fournet B, Leroy Y, Wieruszeski JM, Montreuil J, Poretz RD, Goldberg R: Primary structure of an $\mathrm{N}$-glycosidic carbohydrate unit derived from Sophora japonica lectin. Eur J Biochem 1987;166:321-324.

35 Wicklein D, Lindner B, Moll H, Kolarich D, Altmann F, Becker WM, Petersen A: Carbohydrate moieties can induce mediator release: a detailed characterization of two major timothy grass pollen allergens. Biol Chem 2004;385:397-407.
36 Westphal S, Kolarich D, Foetisch K, Lauer I, Altmann F, Conti A, Crespo JF, Rodriguez J, Enrique E, Vieths S, Scheurer S: Molecular characterization and allergenic activity of Lyc e 2 (beta-fructofuranosidase), a glycosylated allergen of tomato. Eur J Biochem 2003; 270:1327-1337.

-37 Kolarich D, Altmann F, Sunderasan E: Structural analysis of the glycoprotein allergen Hev b 4 from natural rubber latex by mass spectrometry. Biochim Biophys Acta 2006; 1760:715-720.

38 van Ree R, Cabanes-Macheteau M, Akkerdaas J, Milazzo JP, Loutelier-Bourhis C, Rayon C, Villalba M, Koppelman S, Aalberse R, Rodriguez R, Faye L, Lerouge P: $\beta(1,2)$-xylose and $\alpha(1,3)$-fucose residues have a strong contribution in IgE binding to plant glycoallergens. J Biol Chem 2000;275:11451-11458.

-39 Bublin M, Radauer C, Wilson IB, Kraft D, Scheiner O, Breiteneder H, Hoffmann-Sommergruber K: Cross-reactive N-glycans of Api g 5, a high molecular weight glycoprotein allergen from celery, are required for immunoglobulin $\mathrm{E}$ binding and activation of effector cells from allergic patients. FASEB J 2003;17:1697-1699.

40 Kolarich D, Altmann F: N-Glycan analysis by matrix-assisted laser desorption/ionization mass spectrometry of electrophoretically separated nonmammalian proteins: application to peanut allergen Ara h 1 and olive pollen allergen Ole e 1. Anal Biochem 2000; 285:64-75.

41 Lauer I, Foetisch K, Kolarich D, Ballmer-Weber BK, Conti A, Altmann F, Vieths S, Scheurer S: Hazelnut (Corylus avellana) vicilin Cor a 11: molecular characterization of a glycoprotein and its allergenic activity. Biochem J 2004;383:327-334.

$\checkmark 42$ Chow LP, Chiu LL, Khoo KH, Peng HJ, Yang SY, Huang SW, Su SN: Purification and structural analysis of the novel glycoprotein allergen Cyn d 24, a pathogenesis-related protein PR-1, from Bermuda grass pollen. FEBS J 2005;272:6218-6227.

43 Ohsuga H, Su SN, Takahashi N, Yang SY, Nakagawa H, Shimada I, Arata Y, Lee YC: The carbohydrate moiety of the Bermuda grass antigen BG60. New oligosaccharides of plant origin. J Biol Chem 1996;271:26653-26658.

44 Hemmer W, Focke M, Kolarich D, Dalik I, Gotz M, Jarisch R: Identification by immunoblot of venom glycoproteins displaying immunoglobulin E-binding $\mathrm{N}$-glycans as cross-reactive allergens in honeybee and yellow jacket venom. Clin Exp Allergy 2004;34: 460-469.

45 Kubelka V, Altmann F, Marz L: The asparagine-linked carbohydrate of honeybee venom hyaluronidase. Glycoconj J 1995;12:77-83.

46 Kubelka V, Altmann F, Staudacher E, Tretter V, Marz L, Hard K, Kamerling JP, Vliegenthart JF: Primary structures of the N-linked carbohydrate chains from honeybee venom phospholipase A2. Eur J Biochem 1993;213: 1193-1204. 
47 Haslam SM, Reason AJ, Morris HR, Dell A: Core fucosylation of honeybee venom phospholipase A2. Glycobiology 1994;4:105-106.

-48 Kolarich D, Leonard R, Hemmer W, Altmann F: The N-glycans of yellow jacket venom hyaluronidases and the protein sequence of its major isoform in Vespula vulgaris. FEBS J 2005;272:5182-5190.

-49 Khoo KH, Huang HH, Lee KM: Characteristic structural features of schistosome cercarial N-glycans: expression of Lewis X and core xylosylation. Glycobiology 2001;11: 149-163.

50 Dell A, Haslam SM, Morris HR, Khoo KH: Immunogenic glycoconjugates implicated in parasitic nematode diseases. Biochim Biophys Acta 1999;1455:353-362.

- 51 Khoo KH, Chatterjee D, Caulfield JP, Morris HR, Dell A: Structural characterization of glycophingolipids from the eggs of Schistosoma mansoni and Schistosoma japonicum. Glycobiology 1997;7:653-661.

- 52 van Die I, Gomord V, Kooyman FN, van den Berg TK, Cummings RD, Vervelde L: Core $\alpha 1->3$-fucose is a common modification of $\mathrm{N}$-glycans in parasitic helminths and constitutes an important epitope for IgE from Haemonchus contortus infected sheep. FEBS Lett 1999;463:189-193.

-53 Haslam SM, Coles GC, Munn EA, Smith TS, Smith HF, Morris HR, Dell A: Haemonchus contortus glycoproteins contain N-linked oligosaccharides with novel highly fucosylated core structures. J Biol Chem 1996;271: 30561-30570.

54 Mulder H, Dideberg F, Schachter H, Spronk BA, De Jong-Brink M, Kamerling JP, Vliegenthart JF: In the biosynthesis of N-glycans in connective tissue of the snail Lymnaea stagnalis of incorporation GlcNAc by beta 2 GlcNAc-transferase I is an essential prerequisite for the action of beta 2 GlcNAc-transferase II and beta 2Xyl-transferase. Eur J Biochem 1995; 232:272-283.

- 55 Gutternigg M, Ahrer K, Grabher-Meier H, Burgmayr S, Staudacher E: Neutral N-glycans of the gastropod Arion lusitanicus. Eur J Biochem 2004;271:1348-1356.

56 Lommerse JP, Thomas-Oates JE, Gielens C, Preaux G, Kamerling JP, Vliegenthart JF: Primary structure of 21 novel monoantennary and diantennary N-linked carbohydrate chains from $\alpha \mathrm{D}$-hemocyanin of Helix pomatia. Eur J Biochem 1997;249:195-222.

-57 van Tetering A, Schiphorst WE, van den Eijnden $\mathrm{DH}$, van Die I: Characterization of a core $\alpha 1->3$-fucosyltransferase from the snail Lymnaea stagnalis that is involved in the synthesis of complex-type N-glycans. FEBS Lett 1999;461:311-314.

58 Van Die I, Cummings RD: Glycans modulate immune responses in helminth infections and allergy. Chem Immunol Allergy 2006; 90:91-112.

59 Hokke CH, Yazdanbakhsh M: Schistosome glycans and innate immunity. Parasite Immunol 2005;27:257-264.
60 van de Vijver KK, Hokke $\mathrm{CH}$, van Remoortere A, Jacobs W, Deelder AM, Van Marck EA: Glycans of Schistosoma mansoni and keyhole limpet haemocyanin induce hepatic granulomas in vivo. Int J Parasitol 2004;34:951-961.

61 van den Berg TK, Honing H, Franke N, van Remoortere A, Schiphorst WE, Liu FT, Deelder AM, Cummings RD, Hokke $\mathrm{CH}$, van Die I: LacdiNAc-glycans constitute a parasite pattern for galectin-3-mediated immune recognition. J Immunol 2004;173: 1902-1907.

62 van Roon AM, Aguilera B, Cuenca F, van Remoortere A, van der Marel GA, Deelder AM, Overkleeft HS, Hokke CH: Synthesis and antibody-binding studies of a series of parasite fuco-oligosaccharides. Bioorg Med Chem 2005;13:3553-3564.

-63 Wuhrer M, Koeleman CA, Deelder AM, Hokke CH: Repeats of LacdiNAc and fucosylated LacdiNAc on N-glycans of the human parasite Schistosoma mansoni. FEBS I 2006;273:347-361.

64 Robijn ML, Wuhrer M, Kornelis D, Deelder AM, Geyer R, Hokke CH: Mapping fucosylated epitopes on glycoproteins and glycolipids of Schistosoma mansoni cercariae, adult worms and eggs. Parasitology 2005;130:6777.

65 Geyer H, Wuhrer M, Resemann A, Geyer R: Identification and characterization of keyhole limpet hemocyanin N-glycans mediating cross-reactivity with Schistosoma mansoni. J Biol Chem 2005;280:40731-40748.

66 Okano M, Satoskar AR, Nishizaki K, Harn DA Jr: Lacto-N-fucopentaose III found on Schistosoma mansoni egg antigens functions as adjuvant for proteins by inducing Th2type response. J Immunol 2001;167:442450.

67 Cervi L, MacDonald AS, Kane C, Dzierszinski F, Pearce EJ: Cutting edge: dendritic cells copulsed with microbial and helminth antigens undergo modified maturation, segregate the antigens to distinct intracellular compartments, and concurrently induce microbe-specific Th1 and helminth-specific Th2 responses. J Immunol 2004;172:20162020.

68 Pearce EJ, Kane CM, Sun J, Taylor J, McKee AS, Cervi L: Th2 response polarization during infection with the helminth parasite Schistosoma mansoni. Immunol Rev 2004; 201:117-126.

69 Tawill S, Le Goff L, Ali F, Blaxter M, Allen JE: Both free-living and parasitic nematodes induce a characteristic Th2 response that is dependent on the presence of intact glycans. Infect Immun 2004;72:398-407.

70 Faveeuw C, Mallevaey T, Paschinger K, Wilson IB, Fontaine J, Mollicone R, Oriol R, Altmann F, Lerouge P, Capron M, Trottein F: Schistosome N-glycans containing core alpha 3-fucose and core beta 2-xylose epitopes are strong inducers of $\mathrm{Th} 2$ responses in mice. Eur J Immunol 2003;33:1271-1281.
71 Velupillai P, dos Reis EA, dos Reis MG, Harn DA: Lewis $(\mathrm{x})$-containing oligosaccharide attenuates schistosome egg antigen-induced immune depression in human schistosomiasis. Hum Immunol 2000;61:225-232.

72 Yazdanbakhsh M, Kremsner PG, van Ree R: Allergy, parasites, and the hygiene hypothesis. Science 2002;296:490-494.

73 Faye L, Chrispeels MJ: Common antigenic determinants in the glycoproteins of plants, molluscs and insects. Glycoconj J 1988;5: 245-256.

-74 Lauriere C, Lauriere M, Sturm A, Faye L, Chrispeels MJ: Characterization of betafructosidase, an extracellular glycoprotein of carrot cells. Biochimie 1988;70:14831491.

75 Faye L, Gomord V, Fitchette-Laine AC, Chrispeels MJ: Affinity purification of antibodies specific for Asn-linked glycans containing alpha $1->3$ fucose or beta $1->2 \mathrm{xy}-$ lose. Anal Biochem 1993;209:104-108.

76 Petersen A, Vieths S, Aulepp H, Schlaak M, Becker WM: Ubiquitous structures responsible for IgE cross-reactivity between tomato fruit and grass pollen allergens. J Allergy Clin Immunol 1996;98:805-815.

77 Bencurova M, Hemmer W, Focke-Tejkl M, Wilson IB, Altmann F: Specificity of IgG and IgE antibodies against plant and insect glycoprotein glycans determined with artificial glycoforms of human transferrin. Glycobiology 2004;14:457-466.

78 Lommerse JP, Kroon-Batenburg LM, Kamerling JP, Vliegenthart JF: Conformational analysis of the xylose-containing $\mathrm{N}$-glycan of pineapple stem bromelain as part of the intact glycoprotein. Biochemistry 1995;34: 8196-8206.

-79 Bouwstra JB, Spoelstra EC, De Waard P, Leeflang BR, Kamerling JP, Vliegenthart JF: Conformational studies on the $\mathrm{N}$-linked carbohydrate chain of bromelain. Eur J Biochem 1990;190:113-122.

80 Jin C, Bencurova M, Borth N, Ferko B, Jensen-Jarolim E, Altmann F, Hantusch B: Immunoglobulin G specifically binding plant $\mathrm{N}$-glycans with high affinity could be generated in rabbits but not in mice. Glycobiology 2006;16:349-357.

81 Bardor M, Faveeuw C, Fitchette AC, Gilbert D, Galas L, Trottein F, Faye L, Lerouge P: Immunoreactivity in mammals of two typical plant glyco-epitopes, core $\alpha(1,3)$-fucose and core xylose. Glycobiology 2003;13:427-434.

82 Barletta B, Tinghino R, Corinti S, Afferni C, Iacovacci P, Mari A, Pini C, Di Felice G: Arizona cypress (Cupressus arizonica) pollen allergens. Identification of cross-reactive periodate-resistant and -sensitive epitopes with monoclonal antibodies. Allergy 1998; 53:586-593. 
-83 Iacovacci P, Pini C, Afferni C, Barletta B, Tinghino R, Schinina E, Federico R, Mari A, Di Felice G: A monoclonal antibody specific for a carbohydrate epitope recognizes an IgE-binding determinant shared by taxonomically unrelated allergenic pollens. Clin Exp Allergy 2001;31:458-465.

>84 McManus MT, McKeating J, Secher DS, Osborne DJ, Ashford D, Dwek RA, Rademacher TW: Identification of a monoclonal antibody to abscission tissue that recognises xylose/ fucose-containing $\mathrm{N}$-linked oligosaccharides from higher plants. Planta 1988;175: 506-512.

$>85$ van Remoortere A, Bank CM, Nyame AK, Cummings RD, Deelder AM, van Die I: Schistosoma mansoni-infected mice produce antibodies that cross-react with plant, insect, and mammalian glycoproteins and recognize the truncated biantennaryN-glycan $\mathrm{Man}_{3} \mathrm{GlcNAc}_{2}$-R. Glycobiology 2003;13: 217-225.

>86 Geyer H, Wuhrer M, Kurokawa T, Geyer R: Characterization of keyhole limpet hemocyanin $(\mathrm{KLH})$ glycans sharing a carbohydrate epitope with Schistosoma mansoni glycoconjugates. Micron 2004;35:105-106.

$>87$ Afferni C, Iacovacci P, Barletta B, Di Felice G, Tinghino R, Mari A, Pini C: Role of carbohydrate moieties in IgE binding to allergenic components of Cupressus arizonica pollen extract. Clin Exp Allergy 1999;29: 1087-1094.

-88 Mari A, Iacovacci P, Afferni C, Barletta B, Tinghino R, Di Felice G, Pini C: Specific IgE to cross-reactive carbohydrate determinants strongly affect the in vitro diagnosis of allergic diseases. J Allergy Clin Immunol 1999; 103:1005-1011.

-89 Batanero E, Crespo JF, Monsalve RI, MartinEsteban M, Villalba M, Rodriguez R: IgEbinding and histamine-release capabilities of the main carbohydrate component isolated from the major allergen of olive tree pollen, Ole e 1. J Allergy Clin Immunol 1999; 103:147-153.

-90 Foetisch K, Vieths S: N- and O-linked oligosaccharides of allergenic glycoproteins. Glycoconj J 2001;18:373-390.

-91 Hemmer W, Focke M, Kolarich D, Wilson IB, Altmann F, Wohrl S, Gotz M, Jarisch R: Antibody binding to venom carbohydrates is a frequent cause for double positivity to honeybee and yellow jacket venom in patients with stinging-insect allergy. J Allergy Clin Immunol 2001;108:1045-1052.

$>92$ Iacovacci P, Afferni C, Butteroni C, Pironi L, Puggioni EM, Orlandi A, Barletta B, Tinghino R, Ariano R, Panzani RC, Di Felice G, Pini C: Comparison between the native glycosylated and the recombinant Cup al allergen: role of carbohydrates in the histamine release from basophils. Clin Exp Allergy 2002;32:1620-1627.
-93 Sunderasan E, Bahari A, Arif SA, Zainal Z, Hamilton RG, Yeang HY: Molecular cloning and immunoglobulin $\mathrm{E}$ reactivity of a natural rubber latex lecithinase homologue, the major allergenic component of Hev b 4. Clin Exp Allergy 2005;35:14901495.

$\$ 94$ Hiemori M, Bando N, Ogawa T, Shimada H, Tsuji H, Yamanishi R, Terao J: Occurrence of IgE antibody-recognizing N-linked glycan moiety of a soybean allergen, Gly m Bd 28K. Int Arch Allergy Immunol 2000;122: 238-245.

$\$ 95$ Ahrazem O, Ibanez MD, Lopez-Torrejon G, Sanchez-Monge R, Sastre J, Lombardero M, Barber D, Salcedo G: Orange germin-like glycoprotein Cit s 1: an equivocal allergen. Int Arch Allergy Immunol 2006;139:96103.

-96 Yagami T, Osuna H, Kouno M, Haishima Y, Nakamura A, Ikezawa Z: Significance of carbohydrate epitopes in a latex allergen with beta-1,3-glucanase activity. Int Arch Allergy Immunol 2002;129:27-37.

$\checkmark 97$ Hoffman DR, Sakell RH, Schmidt M: Sol i 1 , the phospholipase allergen of imported fire ant venom. J Allergy Clin Immunol 2005; 115:611-616.

98 Jensen-Jarolim E, Schmid B, Bernier F, Berna A, Kinaciyan T, Focke M, Ebner C, Scheiner O, Boltz-Nitulescu G: Allergologic exploration of germins and germin-like proteins, a new class of plant allergens. Allergy 2002;57:805-810.

99 Fahlbusch B, Rudeschko O, Schumann C, Steurich F, Henzgen M, Schlenvoigt G, Jager L: Further characterization of IgE-binding antigens in kiwi, with particular emphasis on glycoprotein allergens. J Investig Allergol Clin Immunol 1998;8:325-332.

100 Sten E, Stahl Skov P, Andersen SB, Torp AM, Olesen A, Bindslev-Jensen U, Poulsen LK, Bindslev-Jensen C: Allergenic components of a novel food, Micronesian nut Nangai (Canarium indicum), shows IgE crossreactivity in pollen allergic patients. Allergy 2002;57:398-404.

101 Foetisch K, Altmann F, Haustein D, Vieths $\mathrm{S}$ : Involvement of carbohydrate epitopes in the IgE response of celery-allergic patients. Int Arch Allergy Immunol 1999;120:3042.

102 Calabozo B, Barber D, Polo F: Studies on the carbohydrate moiety of Pla 11 allergen. identification of a major N-glycan and significance for the immunoglobulin E-binding activity. Clin Exp Allergy 2002;32: 1628-1634.

103 Okano M, Kimura Y, Kino K, Michigami Y, Sakamoto S, Sugata Y, Maeda M, Matsuda F, Kimura M, Ogawa T, Nishizaki K: Roles of major oligosaccharides on Cry j 1 in human immunoglobulin $\mathrm{E}$ and $\mathrm{T}$ cell responses. Clin Exp Allergy 2004;34:770-778.
104 Foetisch K, Fah J, Wuethrich B, Altmann F, Haustein D, Vieths S: IgE antibodies specific for carbohydrates in a patient allergic to gum arabic (Acacia senegal). Allergy 1998;53:1043-1051.

105 Luttkopf D, Ballmer-Weber BK, Wuthrich B, Vieths S: Celery allergens in patients with positive double-blind placebo-controlled food challenge. J Allergy Clin Immunol 2000;106:390-399.

106 Malandain H: Widening sensitization spectrum through carbohydrate panepitopes - a hypothesis. Allerg Immunol (Paris) $2004 ; 36: 297-299$.

107 Malandain H: IgE-reactive carbohydrate epitopes - classification, cross-reactivity, and clinical impact (2nd part). Allerg Immunol (Paris) 2005;37:247-256.

108 Foetisch K, Westphal S, Lauer I, Retzek M, Altmann F, Kolarich D, Scheurer S, Vieths S: Biological activity of IgE specific for cross-reactive carbohydrate determinants. J Allergy Clin Immunol 2003;111:889896.

109 Altmann F, Paschinger K, Dalik T, Vorauer $\mathrm{K}$ : Characterisation of peptide-N4-(N-acetyl-beta-glucosaminyl)asparagine amidase A and its N-glycans. Eur J Biochem 1998; 252:118-123.

110 van Ree R: Carbohydrate epitopes and their relevance for the diagnosis and treatment of allergic diseases. Int Arch Allergy Immunol 2002;129:189-197.

111 Haseley SR, Talaga P, Kamerling JP, Vliegenthart JF: Characterization of the carbohydrate binding specificity and kinetic parameters of lectins by using surface plasmon resonance. Anal Biochem 1999;274:203210.

112 Flicker S, Valenta R: Renaissance of the blocking antibody concept in type I allergy. Int Arch Allergy Immunol 2003;132:1324.

113 Strait RT, Morris SC, Finkelman FD: IgGblocking antibodies inhibit IgE-mediated anaphylaxis in vivo through both antigen interception and Fc gamma RIIb crosslinking. J Clin Invest 2006;116:833-841.

114 Till SJ, Francis JN, Nouri-Aria K, Durham SR: Mechanisms of immunotherapy. J Allergy Clin Immunol 2004;113:1025-1034; quiz 1035.

115 van Ree R, Aalberse RC: Demonstration of carbohydrate-specific immunoglobulin G4 antibodies in sera of patients receiving grass pollen immunotherapy. Int Arch Allergy Immunol 1995;106:146-148.

$>116$ Krop EJ, Stapel SO, De Vrieze H, Van der Zee JS: Immunoglobulin E and G4 antibody responses in occupational airway exposure to bovine and porcine plasma proteins. Int Arch Allergy Immunol 2006;139: $237-244$. 
117 Focke M, Hemmer W, Hayek B, Gotz M, Jarisch R: Identification of allergens in oilseed rape (Brassica napus) pollen. Int Arch Allergy Immunol 1998;117:105-112.

118 Mothes N, Valenta R, Spitzauer S: Allergy testing: the role of recombinant allergens. Clin Chem Lab Med 2006;44:125-132.

119 Reuter A, Lidholm J, Andersson K, Ostling J, Lundberg M, Scheurer S, Enrique E, Cistero-Bahima A, Miguel-Moncin MS, Ballmer-Weber BK, Vieths S: A critical assessment of allergen component-based in vitro diagnosis in cherry allergy across Europe. Clin Exp Allergy 2006;36:815-823.

120 Deinhofer K, Sevcik H, Balic N, Harwanegg C, Hiller R, Rumpold H, Mueller MW, Spitzauer S: Microarrayed allergens for IgE profiling. Methods 2004;32:249-254.

121 Harwanegg C, Hiller R: Protein microarrays for the diagnosis of allergic diseases: state-of-the-art and future development. Clin Chem Lab Med 2005;43:1321-1326.
122 Himly M, Jahn-Schmid B, Dedic A, Kelemen P, Wopfner N, Altmann F, van Ree R, Briza P, Richter K, Ebner C, Ferreira F: Art $\mathrm{v} 1$, the major allergen of mugwort pollen, is a modular glycoprotein with a defensinlike and a hydroxyproline-rich domain. FASEB J 2003;17:106-108.

123 Schmid-Grendelmeier P, Holzmann D, Himly M, Weichel M, Tresch S, Ruckert B, Menz G, Ferreira F, Blaser K, Wuthrich B, Crameri R: Native Art v 1 and recombinant Art $\mathrm{v} 1$ are able to induce humoral and $\mathrm{T}$ cell-mediated in vitro and in vivo responses in mugwort allergy. J Allergy Clin Immunol 2003;111:1328-1336.

124 Dudler T, Altmann F, Carballido JM, Blaser $\mathrm{K}$ : Carbohydrate-dependent, HLA class IIrestricted, human $\mathrm{T}$ cell response to the bee venom allergen phospholipase A2 in allergic patients. Eur J Immunol 1995;25:538542 .

125 Jensen T, Hansen P, Galli-Stampino L, Mouritsen S, Frische K, Meinjohanns E, Meldal M, Werdelin O: Carbohydrate and peptide specificity of MHC class II-restricted $\mathrm{T}$ cell hybridomas raised against an $\mathrm{O}$ glycosylated self peptide. J Immunol 1997; 158:3769-3778.
126 Adedoyin J, Johansson SG, Gronlund H, van Hage $M$ : Interference in immunoassays by human IgM with specificity for the carbohydrate moiety of animal proteins. J Immunol Methods 2006;310:117-125.

127 Koshte VL, van Dijk W, van der Stelt ME, Aalberse RC: Isolation and characterization of BanLec-I, a mannoside-binding lectin from Musa paradisiac (banana). Biochem J 1990;272:721-726.

128 Wong KN, Ong TC, Wang X, Lee WSe, Lim PA, Wang DeY, Chew FT: Deglycosylation of meat extracts reduced the binding of cross-reactive antibodies to meat. XVth Annual Congress of the European Academy of Allergology and Clinical Immunology, Vienna, June 10-14, 2006.

129 Herndl A, Marzban G, Kolarich D, Hahn R, Boscia D, Hemmer W, Maghuly F, Stoyanova E, Katinger H, Laimer M: Mapping of Malus domestica allergens by twodimensional electrophoresis and IGE-reactivity. Electrophoresis 2006, in press. 